Jurnal KONTEKSTUAL

Volume 01, No. 1, Agustus 2019, p. 70-76

\title{
PELAKSANAAN PENILAIAN PEMBELAJARAN MENGGUNAKAN KURIKULUM 2013 DI SD NEGERI 1 TAPAK
}

\author{
Sasi Mardikarini*1, Fahrudin Hamdani ${ }^{2}$ \\ ${ }^{1,2}$ Prodi Pendidikan Guru Sekolah Dasar, Fakultas Keguruan dan Ilmu Pendidikan, \\ Universitas Doktor Nugroho Magetan, Indonesia \\ e-mail : sasimardikarini09@gmail.com
}

\begin{abstract}
Abstrak
Penelitian ini bertujuan untuk 1) Mengetahui bentuk- bentuk penilaian pembelajaran menggunakan Kurikulum 2013 di Sekolah Dasar Negeri 1 Tapak, Panekan, Magetan. 2) Mengetahui masalah- masalah yang dihadapi oleh guru dalam melaksanakan penilaian pembelajaran menggunakan Kurikulum 2013. Penelitian ini merupakan penelitian kualitatif. Teknik pengumpulan menggunakan teknik wawancara, observasi, dan dokumentasi. Teknik analisis data menggunakan teknik pengumpulan data, reduksi data, penyajian data, serta penarikan kesimpulan. Hasil penelitian terlihat bahwa 1) bentuk penilaian pembelajaran menggunakan Kurikulum 2013 terdiri dari penilaian pengetahuan, penilaian sikap, dan penilaian keterampilan. Penilaian pengetahuan diambil berdasarkan tugas individu, tugas kelompok, ulangan, PR, dan dalam proses pembelajaran. Penilaian sikap diambil berdasarkan aktifitas yang dilakukan oleh siswa sehari- hari selama di sekolah, sedangkan keterampilan sesuai dengan kegiatan selama proses pembelajaran. Untuk penilaian sikap dan keterampilan belum berjalan secara maksimal. 2) Guru terkendala dengan pengalaman, materi yang cukup, waktu, dan partner kerja.
\end{abstract}

Kata Kunci : Penilaian, Pembelajaran, Kurikulum 2013

\begin{abstract}
This study aims to 1) Determine the forms of learning using the 2013 Curriculum in State Elementary School 1 Tapak, Panekan, Magetan. 2) Knowing the problems done by teachers in implementing Learning using the 2013 Curriculum. This study is a qualitative study. Collection techniques using interview, observation, and documentation. Data analysis techniques using data collection techniques, data reduction, data presentation, and conclusion collection. The results of the study show that 1) the form of learning using the 2013 curriculum consists of knowledge, assessment, and expertise. Knowledge assessment is based on individual assignments, group assignments, tests, homework, and in the learning process. Attitude assessment is based on activities carried out by students daily while at school, while the skills are in accordance with activities during the learning process. To appreciate attitudes and difficulties is not optimal. 2) Teachers are constrained by experience, sufficient material, time, and work partners.
\end{abstract}

Key Word : assessment, learning, Kurikulum 2013

\section{PENDAHULUAN}

Undang- undang Nomor 20 tahun 2003 tentang sistem pendidikan nasional menjelaskan bahwa pendidikan merupakan "usaha sadar dan terencana untuk mewujudkan suasana belajar dan proses pembelajaran agar peserta didik secara aktif mengembangkan potensi dirinya untuk memiliki kekuatan spiritual keagamaan, kecerdasan, akhlak mulia, serta keterampilan yang diperlukan dirinya, masyarakat, bangsa dan negara". Pengertian tersebut menjelaskan bahwa pendidikan merupakan kegiatan yang direncana atau dirancang sedemikian rupa sehingga dalam pelaksanaannya dapat mewujudkan semua hal- hal yang perlu ditanamkan. 
JurnalKONTEKSTUAL, Volume 01, No. 1, Agustus 2019, pp. 70-76

Dalam rangka mewujudkan pendidikan Indonesia yang semakin baik, pemerintah selalu berupaya memperbaiki kurikulum yang sedang berjalan. Salah satu usaha pemerintah untuk memperbaiki dunia pendidikan adalah dengan meluncurkan kurikulum terbaru yaitu kurikulum 2013. Terdapat beberapa hal yang membedakan kurikulum 2013 dengan kurikulum sebelumnya, salah satu yang paling menonjol adalah bagian penilaian.

Penjelasan tersebut sejalan dengan penelitian [1] bahwa proses pembelajaran sepenuhnya diarahkan pada pengembangan ketiga ranah (kognitif, afektif, psikomotor) tersebut secara utuh, artinya pengembangan ranah yang satu tidak bisa dipisahkan dengan ranah lainnya. Penilaian kognitif, afektif, dan psikomotor dalam kurikulum 2013 lebih populer dengan nama pengetahuan, sikap dan keterampilan.

Ketiga ranah tersebut perlu diterapkan sesuai dengan porsinya tanpa mengurangi salah satunya. Pada beberapah sekolah, guru banyak menonjolkan ranah pengetahuannya saja karena sesuai dengan kurikulum tingkat satuan pendidikan. Guru menganggap bahwa pembelajaran yang paling utama adalah ilmu pengetahuan saja, sedangkan ranah sikap dan keterampilan masih dianggap sepele.

Selain menganggap remeh ranah sikap dan keterampilan, sebagian besar guru merasa kesulitan dalam mencari cara untuk mengembangkan pembelajaran menggunakan ranah sikap dan keetrampilan. Gurupun merasa kesulitan dengan proses penilaian yang mereka hadapi.

Banyaknya penilaian yang harus dilakukan oleh guru tersebut membuat guru harus banyak belajar mengenai kemajuan pendidikan yang terjadi. Pembaharuan proses penilaian melalui pembaharuan Kurikulum 2013 tersebut membuat beberapa guru yang baru pernah melaksanakan merasa kewalahan. Salah satunya yang terjadi di Sekolah Dasar Negeri 1 Tapak, Kecamatan Panekan, Kabupaten Magetan. Pada tahun 2017/2018 merupakan tahun pertama dilaksanakanya Kurikulumm 2013. Sebagai permulaan, pelaksanaan Kurikulum 2013 dilakukan di kelas I dan IV.

Penilaian pembelajaran dinilai sangat berbeda, dan sulit untuk dilaksanakan. Guru sekolah dasar yang pada umunya dalam satu kelas hanya diampu oleh 1 guru dipaksa untuk menilai spiritual, sikap, keterampilan, dan pengetahuan siswa dalam waktu yang bersamaan. Ditambah lagi, jumlah siswa yang cukup banyak dan waktu yang singkat membuat penilaian belum tentu bisa dilaksakan dengan maksimal. Berdasarkan beberapa alasan tersebut, peneliti ingin melihat pelaksanaan penilaian pembelajaran menggunakan kurikulum 2013 di SD Negeri 1 Tapak, Kecamatan Panekan, Kabupaten Magetan.

Penelitian ini bertujuan untuk 1) untuk mengetahui bentuk- bentuk penilaian pembelajaran menggunakan kurikulum 2013 di sekolah dasar, dan 2) untuk mengetahui masalah- masalah yang dihadapi oleh guru dalam melaksanakan penilaian pembelajaran menggunakan kurikulum 2013.

\section{KAJIAN TEORI}

Menurut peneliti [2] kurikulum merupakan suatu kegiatan yang bertujuan untuk mewujudkan atau melaksanakan kurikulum (dalam arti rencana tertulis) ke dalam bentuk nyata di kelas, yaitu terjadinya proses transmisi dan transformasi segenap pengalaman belajar kepada peserta didik. Pendapat tersebut merupakan suatu rencana dengan tujuan untuk saling 
JurnalKONTEKSTUAL, Volume 01, No. 1, Agustus 2019, pp. 70-76

mentransformasi ilmu yang dimiliki oleh peserta didik.

Kurikulum untuk pendidikan di Indonesia yang terbaru yaitu kurikulum 2013. Kurikulum 2013 merupakan kurikulum terbaru yang diluncurkan oleh Departemen Pendidikan Nasional mulai tahun 2013 ini sebagai bentuk pengembangan dari kurikulum sebelumnya yaitu kurikulum 2006 atau Kurikulum Tingkat Satuan Pendidikan yang mencangkup kompetensi sikap, pengetahuan, dan keterampilan secara terpadu[3].

Menurut peneliti [4] menjelaskan bahwa kurikulum 2013 merupakan kurikulum yang terintegrasi, maksudnya suatu model kurikulum yang dapat mengintegrasikan skill, themes, concepts, and topics baik dalam bentuk within singel disciplines, across several disciplines and within and across learners. Hal ini menyatakan bahwa kurikulum 2013 merupakan sebuah sistem pendekatan pembelajaran yang melibatkan pengalaman yang bermakna dan luas untuk peserta didik.

Kurikulum 2013 memberikan gebrakan baru bagi pendidikan di Indonesia. Kurikulum ini mendorong pada guru untuk mengembanbangkan diri dalam mendidik generasi bangsa salah satunya dengan menanamkan ranah pengetahuan, sikap dan keterampilan menjadi satu kesatuan yang tidak dapat dipisahkan. Hal ini didukung oleh peneliti [5] yang menyatakan bahwa kurikulum 2013 lebih menekankan pada kompetensi yang berbasis sikap, keterampilan, dan pengetahuan.

Penilaian sikap pada Kurikulum 2013 terdiri dari 2 jenis yaitu penilaian sikap selama proses pembelajaran dan penilaian spiritual siswa selama berada di sekolah. Penilaian sikap disesuaikan dengan sikap-sikap yang dapat ditanamkan selama proses pembelajaran tersebut. Guru dapat memilih atau menentukan sikap yang akan ditanamkan dan bagaimana cara penanamanya. Sedangkan untuk sikap spiritual lebih menekankan kepada penanaman nilai religius. Menurut peneliti [6] bahwa religius merupakan ketaatan dan kepatuhan dalam memahami dan melaksanakan ajaran agama (aliran kepercayaan) yang dianut, termasuk dalam hal ini adalah sikap toleran terhadap pelaksanaan ibadah agama (aliran kepercayaan) lain, serta hidup rukun dan berdampingan.

Proses penilaian sikap dapat dilakukan melalui observasi, serta penilaian diri. Menurut peneliti [7] observasi merupakan Mengumpulkan data atau keterangan yang harus dijalankan dengan melakukan usahausaha pengamatan secara langsung ke tempat yang akan diselidiki.

Penilaian melalui observasi dapat dilakukan untuk seorang siswa yang menonjol pada pertemuan tersebut, namun dapat juga dilakukan untuk semua siswa yang ada dalam kelas tersebut. Sedangkan penilaian diri yaitu penilaian yang dilakukan sendiri oleh siswa melalui angket yang diberikan oleh guru.

Menurut Lubna Assagaf dalam buku pegangan guru tema diriku kelas 1 menjelaskan bahwa penilaian diri digunakan untuk memberi penguatan (reinforcement) terhadap kemajuan belajar siswa[8]. Penilaian diri memberi peluang kepada siswa untuk memonitor, memberi penilaian, dan mengevaluasi perkembangan belajarnya sendiri. Kedua penilaian ini wajib dilakukan guru selama proses pembelajaran berlangsung untuk melihat kemajuan sikap siswa.

Selain penilaian sikap, terdapat juga penilaian pengetahuan yang wajib dilakukan guru. Penilaian pengetahuan merupakan pengambilan nilai pengetahuan atau nilai kognitif siswa 
setelah mengikuti proses pembelajaran. Penilaian pengetahuan dapat diambil sebelum atau setelah mengikuti proses pembelajaran baik di kelas maupun di luar kelas.

Dalam penilaian pengetahuan, terdapat beberapa teknik dan instrumen penilaiannya, bahwa teknik penilaian ada 3 yaitu tes tertulis, tes lisan, dan penugasan[8]. Penilaian ini hampir sama dengan instrumen penilaian- penilaian selanjutnya.

Penilaian selanjutnya yang harus dilakukan oleh siswa yaitu penilaian keterampilan. Keterampilan merupakan proses yang dijalani peserta didik untuk menerima pembelajaran. Penilaian keterampilan dimaksudkan untuk mengetahui kemampuan siswa untuk menetapkan pengetahuan dalam memahami dan menyelesaikan masalah. Penilaian keterampilan diambil selama proses pembelajaran berlangsung. Dalam pengambilan penilaian, guru juga harus memiliki pedoman penskoran. Penilaian keterampilan antara lain dapat dilakukan melalui penilaian kinerja dan penilaian portofolio.

\section{METODE PENELITIAN}

Penelitian ini dilaksanakan di Sekolah Dasar Negeri 1 Tapak, Kecamatan Panekan, Kabupaten Magetan. Penelitian dikhususkan pada guru kelas I dan IV yang telah melaksanakan Kurikulum 2013. Waktu penelitian dilaksanakan mulai tanggal 24 April 2019 hingga 11 Mei 2019. Penelitian ini merupakan penelitian kualitatif. Sumber data diambil dari data primer dan data sekunder. Data primer terdiri dari guru kelas, kepala sekolah, dan teman guru. Sedangkan data sekunder diambil dari RPP pembelajaran, hasil penilaian yang telah dilakukan guru, dan dokumentasi pendukung.
Teknik pengumpulan data dilakukan melalui observasi, interview, serta dokumentasi. Observasi dilakukan peneliti selama proses pembelajaran yang dilakukan guru di kelas, interview dilakukan untuk mendukung penelitian, dan ditambah dengan dokumentasi. Teknik analisis data yang dilakukan yaitu terdiri dari data collection/ pengumpulan data, data reduction (reduksi data), data display/ penyajian data, dan conclusion/ kesimpulan[9].

\section{HASIL DAN PEMBAHASAN}

Penilaian tersebut dilaksanakan dalam 3 bentuk, yaitu penilaian pengetahuan, penilaian sikap dan penilaian keterampilan. Ketiga penilaian tersebut dijelaskan sebagai berikut.

1. Penilaian Pengetahuan

Penilaian pengetahuan dirasa tidak terlalu berat dibandingkan dengan penilaian lainnya. Penilaian pengetahuan di SD Negeri 1 tapak dilaksanakan atau diambil melalui tugas- tugas yang diberikan kepada siswa baik tugas tertulis maupun bukan. Selain itu juga dapat dilihat melalui ulangan harian siswa, dan ulangan pertema yang dilakukan setelah satu tema selesai diberikan. Untuk bentuk soal biasanya akan dibuat sendiri oleh guru maupun diambilkan dari buku tugas dan LKS yang dimiliki siswa.

Pelaksanaan penilaian pengetahuan lebih banyak dilakukan lewat tugas harian siswa baik tugas kelompok maupun tugas individu. Variasi yang dilakukan guru setiap hari disesuaikan dengan kesibukan guru dan materi yang akan diberikan. keadaan ini sejalan dengan muatan buku pegangan guru bahwa teknik penilaian untuk pengetahuan terdiri dari macam bentuk yaitu tertulis, tes lisan dan penugasan. Bentuk- bentuk tersebut 
dapat divariasikan sesuai dengan kegiatan yang akan dilakukan dan materi yang disampaikan. Selain itu, juga wajib disesuaikan dengan kondisi siswa.

2. Penilaian Sikap

Penilaian sikap yang dilaksanakan di SD Negeri Tapak dilaksanakan dalam bentuk yaitu penilaian sikap spiritual dan penilaian sikap. Sikap spiritual dinilai dari proses kegiatan seharihari yang diawali dan diakhiri dengan berdoa dan memberi salam. Selain itu, guru juga memberikan kebebasan kepada siswa untuk berdoa sesuai agama dan kepercayaannya.

Kegiatan ini sejalan dengan pendapat peneliti [6] bahwa religius merupakan ketaatan dan kepatuhan dalam memahami dan melaksanakan ajaran agama (aliran kepercayaan) yang dianut, termasuk dalam hal ini adalah sikap toleran terhadap pelaksanaan ibadah agama (aliran kepercayaan) lain, serta hidup rukun dan berdampingan. Namun menurut guru kelas I, penilaian spiritual tersebut belum maksimal karena baru berpusat pada doa sebelum dan sesudah pembelajaran saja.

Untuk penilaian sikap secara umum dilakukan selama proses pembelajaran dan diluar pembelajaran. Proses antara membimbing dan menilai dilaksanakan dalam waktu yang sama yaitu saat siswa di sekolah. Guru mengalami kendala yaitu sulitnya mengajarkan nilai sikap kepada siswa sesuai dengan materi yang diajarkan.

Selain itu, guru juga mengalami kesulitan mengenai format penilaian yang berbagai macam dan dilaksanakan sendiri di dalam kelas.
Untuk mengatasi hal tersebut, guru kelas I dan IV menggunakan cara yaitu membuat format yang sama untuk pertema dan dipersiapkan sebelum proses pembelajaran.

Selama proses pengamatan terlihat bahwa guru menilai nilai spiritual dan sikap melalui observasi saja tanpa melakukan penilaian diri. bahkan beberapa pertemuan melakukan penilaian yang sama karena format sudah dibuat sejak awal. Kegiatan ini sejalan dengan format penilaian yang ada pada buku pegangan guru dimana salah satu format penilaian yang dapat dilakukan adalah observasi. Namun, alangkah baiknya jika dikemudian hari guru selalu membuat format penilaian setiap hari disesuaikan dengan nilai sikap yang akan diamati pada hari tersebut. Selain itu, guru diharapkan juga sering membuat lembar penilaian diri siswa, karena merupakan salah satu bentuk penilaian sikap dalam pelaksaan pembelajaran menggunakan Kurikulum 2013.

3. Penilaian Keterampilan

Penilaian keterampilan menggunakan Kurikulum 2013 dapat dilihat melalui kegiatan yang dilakukan siswa pada proses pembelajaran. Pada pelaksanaan Kurikulum 2013 di SD Negeri 1 Tapak biasanya guru melakukan penilaian keterampilan melalui produk dan penilaian portofolio. Penilaian produk dinilai dari hasil tugas siswa dalam pembelajaran di kelas seperti hasil diskusi, hasil kerajinan, dll. Sedangkan hasil portofolio seperti kumpulan tugastugas, foto atau video, dll. Kegiatan ini sejalan dengan aturan penilaian keterampilan Kurikulum 2013 pada buku guru yaitu berupa penilaian produk dan penilaian portofolio. 
JurnalKONTEKSTUAL, Volume 01, No. 1, Agustus 2019, pp. 70-76

Namun, masih ada satu bentuk penilaian yang belum dilaksanakan oleh guru yaitu penilaian proses.

Penilaian proses dilaksanakan selama proses pembelajaran. Guru menilai siswa dalam membuat tugas, diskusi kelompok, presentasi kelompok/ individu, dll. Kegiatan ini belum dilaksanakan secara maksimal dan masih memiliki kendala antara lain guru kelas I dan IV di SDN 1 Tapak karena alasan tidak cukup waktu untuk menilai. Jika guru fokus menilai maka proses pembelajaran dapat terbengkalai, atau siswa akan ramai sendiri. Hal ini menjadi kendala utama dalam pelaksanaan Kurikulum 2013.

\section{SIMPULAN}

Proses penilaian sesuai aturan Kurikulum 2013 telah dilaksanakan oleh guru kelas I dan IV. Namun, untuk penilaian sikap dan keterampilan belum dilaksanakan secara maksimal karena masih memiliki beberapa kendala seperti kurang pengetahuan, baru melaksanakan Kurikulum 2013, dan terlalu banyak penilaian yang harus dilaksanakan dengan kondisi guru kelas sendiri.

Sebaiknya, sering dilaksanakan pelatihan atau workshop dan evaluasi pelaksanaan penilaian Kurikulum 2013. Kegiatan ini bertujuan untuk membantu guru yang masih pemula untuk lebih paham dan lebih baik lagi dalam pelaksanaan Kurikulum 2013 di sekolah dasar.

\section{REFERENSI}

[1] Kurniawan, Otang., Noviana. E., 2017. Penerapan Kurikulum 2013 dalam Meningkatkan Keterampilan Sikap dan Pengetahuan. Jurnal Primary
Program Studi Pendidikan Guru

Sekolah DasarFakultas

Keguruan dan Ilmu Pendidikan

Universitas Riau, Vol 6 No2.

[2] Suyatmini. 2017. Implementasi Kurikulum 2013 pada

Pelaksanaan Pembelajaran

Akuntansi di Sekolah Menengah Kejuruan. Jurnal Pendidikan Ilmu Sosial, Vol 27, No 1, Juni 2017. UMS

[3] Mardiana, S. Sumiyatun., 2017. Implementasi Kurikulum 2013 dalam Pembelajaran Sejarah di SMA Negeri 1 Metro. Jurnal HISTORIA, Vol 5, No. 1. Available:

http://ojs.fkip.ummetro.ac.id/ind ex.php/sejarah/article/view/732

[4] Loeloek Endah Poerwati. 2013. Panduan Memahami Kurikulum 2013. Jakarta: PT Prestasi Pustakarya.

[5] Kurniasih, Imas dan Berlin, Sani. 2014. Implementasi Kurikulum 2013 Konsep dan Penerapan. Yogyakarta: Kata Pena.

[6] Suyadi. 2013. Strategi pembelajaran pendidikan karakter. Bandung: PT Remaja Rosdakarya

[7] Suharsimi Arikunto. 2006. Prosedur Penelitian Suatu Pendekatan Praktik. Jakarta: Rineka Cipta.

[8] Lubna Assagaf, dkk. (2014a). Buku tematik terpadu Kurikulum 2014, tema 1: diriku (buku guru SD/MI kelas I). Jakarta: Pusat Kurikulum dan Perbukuan, Balitbang, Kemdikbud.

[9] Miles, B. Mathew And Michael Huberman. 2007. Analisis Data Kualitatif Buku Sumber tentang Metode- metode Baru. 
JurnalKONTEKSTUAL, Volume 01, No. 1, Agustus 2019, pp. 70-76

terjemahan Tjetjep Rohendi

Rohisi. Jakarta: Universitas

Indonesia. 